\title{
White Voter Support for Southern Black Congressional Candidates
}

\author{
Charles S. Bullock, III and Richard E. Dunn
}

In the wake of Miller v. Johnson (1995) which required redrawing of congressional districts in order to conform with the U.S. Constitution, African Americans have begun winning elections in majority-white southern congressional districts. Three hypotheses to account for the increased rates of white voter support are examined. The incumbency hypothesis explains black victories in terms of increased white support which comes in response to the activities of the incumbent. The color blind white hypothesis suggests that white voters are no more likely to reject a black Democrat candidate than a white Democrat. The greater tolerance hypothesis suggests that while African Americans now get larger shares of the white vote than in the past, they still run less well than white Democrats. Evidence from almost 100 congressional elections shows that although greater percentages of the white electorate votes for black candidates than in the past, black Democrats continue to attract smaller shares of the white vote than to white Democrats. This pattern maintains after controlling for incumbency, campaign spending, candidate experience and white partisanship.

Between 1972 and 1994, black candidates won 72 of 5079 elections in majority white congressional districts but succeeded in all but 19 of 219 elections held in majority black districts (Lublin 1997, 41). Winning 1.4 percent of the contests in white districts prompts Lublin to observe that "These few elections spark little hope that blacks can frequently win election from majority white districts" (p. 42). Yet from 1996-2000, six African Americans won reelection a total of 17 times in majority white districts in four southern states. Some additional southern districts were drawn after the 2000 census with African American concentrations below 50 percent, yet these are expected to elect blacks. Why have black prospects in districts with narrow white majorities improved? Are black candidates simply reaping the rewards of incumbency or has race become less significant for white voters?

The research presented here examines the degree to which southern whites voted for black congressional candidates during the 1990s. We seek to determine whether black nominees continue to pay a penalty for their race. Do blacks poll smaller shares of the white vote than do comparable white nominees? To answer this question, we analyze almost 100 congressional contests controlling for the race of the Democratic nominee, incumbency, candidate quality and the political leanings of the district.

CHARLES S. BULLOCK, III is Richard B. Russell Professor of Political Science at the University of Georgia. RICHARD E. DUNN is with the Department of Human Resources, State of Georgia.

The American Review of Politics, Vol. 24, Fall, 2003: 249-265

(C)2003 The American Review of Politics 


\section{Background and Hypotheses}

Unless white turnout is exceptionally low and black turnout atypically high so that more black than white voters go to the polls, African Americans must attract a share of the white electorate to win predominantly white districts. While Gay (2001) shows that white turnout is often lower in districts represented by an African American, our research indicates that black victories have not been the result of black turnout exceeding white turnout.

Historically, voting in southern elections involving a black candidate could be described by a racial threat or white backlash model and it was this model that guided the Department of Justice's (DOJ) redistricting policy until Shaw v. Reno (1993). Evidence from elections held in the 1970s and early 1980s showed black and white voters cohesive with black voters favoring black candidates while whites united in opposition (Loewen 1982). An analysis of 130 South Carolina elections in which black candidates opposed whites found that, on average, 90 percent of the white voters supported a candidate of their race and 85 percent of the African-American voters supported a black candidate (Loewen 1987). The qualifications of black candidates seemed to make little if any difference to white voters - the race of the candidates provided almost perfect predictability. Black voters might vary in the level of support given a black candidate depending on candidate qualifications, campaigning and incumbency status, but whites consistently rejected these efforts (Loewen 1982). The assumption that black candidates could not attract white votes regardless of candidate qualifications drove DOJ demands as it implemented its responsibilities to pre-clear redistricting proposals pursuant to Section 5 of the 1965 Voting Rights Act. This assumption also influenced judges hearing voting rights challenges and shaped the behavior of many legislators involved in the redistricting process at the beginning of the 1990 s.

At times, DOJ and some federal judges seemingly used a 65 -percent rule when reviewing districting plans. This standard grew from the belief that for black candidates to have an equal opportunity at electoral victory, districts would have to be 65 percent black to compensate for lower registration and turnout rates among blacks than whites and because a smaller share of the black than white population was of voting age (Loewen 1982; Brace et al. 1988). As evidence of the presence of the 65-percent rule in DOJ Section 5 reviews, in 1981, Justice refused to pre-clear Georgia's 5th Congressional district which had been increased to 57 percent black after having elected Andrew Young (D) to Congress when majority white. ${ }^{1}$ DOJ indicated that it would approve at 65 percent. Once the state increased the black percentage to 65.02 , DOJ granted approval. 
While a 65-percent rule was not applied to plans drawn in the early 1990s, a desire to make districts as black as possible motivated some of those involved in redistricting. Georgia's Legislative Black Caucus (Holmes 1998) and African Americans in the South Carolina House (Burton 1998) sought to boost black percentages in congressional and state legislative districts, believing that high concentrations were necessary to elect blacks. In Louisiana, a political scientist and a state legislator testified that congressional districts in which blacks constituted as much as 63.2 percent of the population did not guarantee the election of African Americans (Engstrom and Kirksey 1998). Virginia's Governor Doug Wilder vetoed a 61.5 percent black congressional district and countered with a plan that raised the percentage to 63.9 (Hagens 1998).

In the early 1990s, new congressional districts were drawn at more than 60 percent black in Alabama, Georgia, Louisiana, South Carolina, and Virginia. In Florida, Georgia, North Carolina, and Texas, black concentrations were pushed above 50 percent even though doing so necessitated ignoring political boundaries and required splitting precincts. To draw Georgia's 57 percent black 2nd District, computer technicians went block-by-block, bringing majority black blocks into the district while excluding ones with white majorities (Bullock and Dunn 1999). ${ }^{2}$

Consequences of efforts to maximize black populations in selected districts are (1) fewer districts with black concentrations and (2) more heavily white neighboring districts which in the South means more districts with Republican concentrations. Blacks now win all majority-black congressional districts in the South. ${ }^{3}$

Cameron and colleagues (1996) estimate that blacks have a 50-50 chance of winning southern congressional districts once the African-American voting age population exceeds 40 percent. At the state level, Burton (1998) reports that South Carolina blacks won 85 percent of the contests in legislative districts more than 57 percent black in population. Epstein and O'Halloran (1999) estimate that beyond 47 percent black voting age population, blacks are more likely than not to win South Carolina state senate seats. In Georgia, from 1982-1992, blacks won 86 percent of state legislative contests in districts at least 60 percent black and 79 percent of the elections when the black population exceeded 55 percent (Bullock 1996). While lowering black concentrations in legislative districts does incur risk, it might be offset by creating additional districts with some potential of electing an African American. ${ }^{4}$ Maximizing black concentrations not only reduces the number of districts that might elect blacks but almost certainly increases the number of districts that elect Republicans (Bullock 1987; Brace, Grofman and Handley 1987). Although the exact number of congressional seats picked up by the GOP as a result of racial gerrymandering is subject to 
debate, few who have studied the results deny that Republicans gained an advantage (for a review of estimates of GOP gains in 1992 and 1994, see Lublin 1997, 111-114, although Engstrom [1995] claims that no Democratic seats were lost due to racial gerrymandering).

Many of the more extreme efforts to maximize black concentrations have been undone by court challenges in the wake of Shaw v. Reno and Johnson v. Miller. Two congressional districts each in Georgia, Texas, and North Carolina and one each in Florida, Louisiana, and Virginia had their black percentages reduced. Of these only NC-1 and VA-3 remained majority black after redistricting. None of the affected members who sought reelection in new, whiter districts has lost. ${ }^{5}$ The ability of African-American members of Congress to retain their seats after court orders mandated redistricting has prompted questions about the willingness of whites to vote for black candidates and the requisite black population for electing African Americans.

At least three hypotheses challenge the white backlash model and could explain the recent black victories in predominantly white districts. One possibility is the "incumbency hypothesis" offered by Rep. Cynthia McKinney (D-GA), who won reelection three times from a district in which the 1990 population was 37 percent black. ${ }^{6}$ She asserts that she won in a majoritywhite district drawn after Miller v. Johnson (1995) invalidated her 64 percent black district because two terms of service in the old district made her a more formidable candidate. She opined that:

\footnotetext{
Representing that majority-minority district for $3 \frac{1}{2}$ years enabled me to develop a track record, name recognition, and the local and national contacts necessary to raise the nearly $\$ 1$ million I spent to win in the new Fourth District. . . . Hence, my victory says more about the power of incumbency than anything else (1996, A 15).
}

McKinney's explanation is in line with studies of municipal elections that find that with incumbency black candidates attract larger shares of the white vote (Bullock 1984; Watson 1984; Vanderleeuw 1989; Liu and Vanderleeuw 1999). Hajnal (2001) suggests that when black officeholders succeed, they prompt some whites to abandon fears and stereotypes rooted in a lack of information and become more willing to support the black incumbents' reelection. Voss and Lublin (2001) however challenge McKinney's explanation. Their careful analysis shows that she polled a smaller share of the white vote in the precincts she had previously represented than in the precincts added to her district in 1996. Even if incumbency may not have helped McKinney, Hajnal's (2001) more general proposition may be accurate. 
An alternative to McKinney's proposition, the "colorblind white hypothesis," holds that white voters have become more accepting of black candidates, regardless of their electoral status (Thernstrom and Thernsrtom 1997). Hajnal (2001) reports that Democrats and independents, but not Republicans, are more tolerant in cities that have had black mayors. This suggests that in communities that have experienced black leadership, Democrats and independents may become more willing to support not just specific incumbents but black candidates more generally. As the white electorate becomes increasingly Republican, whites who continue to be loyal to the Democratic Party are less conservative and less likely to discriminate against black candidates. These white Democrats constitute a share of the white electorate that does not reject all black candidates.

According to the colorblind hypothesis, partisanship has become such a force in congressional contests that it overrides race of the candidate. Thus while most white voters will not support a black Democrat, neither will they support a white Democrat. Exit polls show that in 1996 when challenging Jesse Helms (R-NC), Harvey Gantt, who is black, attracted 36 percent of the white vote, a figure about three points higher than the average for nine white Democrats running for the Senate in the South that year (Bullock and Rozell 1998, 12). The Gantt share is in line with the proportion of the white vote cast for recent Democratic presidential and congressional candidates in the South (Bullock and Rozell 1998, 11).

A modification of the color blind hypothesis is the "greater tolerance hypothesis." This suggests that whites have become more willing to vote for black candidates even though a share of the white electorate continues to apply a racial litmus test. Thus black candidates may get less of the white vote than white candidates but a larger share than won by blacks in the past.

Research reported here examines white support for Democratic congressional candidates in the South during the 1990s in an effort to determine how white support for black candidates compares with that given similarly situated whites. We do not focus on black voting behavior because of the near unanimity with which African Americans vote for Democrats. Only one black candidate is estimated to have secured less than 93 percent of the black vote. With such consistent black support, the political success of African Americans hinges on white support if the bulk of the electorate is not black.

\section{Data and Methods}

The elections examined come primarily from Georgia, North Carolina and South Carolina from 1992 through 1998. ${ }^{7}$ Though not a random sample of all House races in the region during this period, the data set includes most elections in three of the five southern states that maintain registration data by 
race. ${ }^{8}$ Precinct-level data are needed to estimate white voting preferences reliably. We have supplemented the data with results from additional congressional elections in Florida, Louisiana, Texas, and Virginia. ${ }^{9}$ Estimates of white voting behavior in these contests - each of which featured a black Democratic nominee - come from testimony offered in cases challenging district plans.

For the 86 general elections for which we obtained precinct-level registration data and electoral results, three estimates of white voting behavior were developed and serve as dependent variables in the analysis that follows. ${ }^{10}$ Two of these estimates, ecological regression (OLS) and homogeneous precinct analysis (HP), have been widely employed in voting rights litigation. The third and newer technique, ecological inference (EI) (King 1997), has the advantage of not yielding estimates of racial support greater than 100 percent or less than zero. In seven instances where we take the estimates of white support for Democratic candidates from court documents, the EI estimates are missing since the analysts did not include that approach in their reports.

In testing the colorblind white electorate hypothesis and the incumbency hypothesis, we control for other systematic factors that may influence whites' willingness to support Democratic candidates. In making comparisons among white and black Democratic candidates, it is especially important to control for the candidate's status as a challenger, open seat candidate, or incumbent. The white vote share won by black Democratic candidates will be compared with that won by white Democratic candidates with the same electoral status. As Table 1 shows, almost 80 percent of the cases involve either Democratic challengers or incumbents. African-Americans competed in a third of the contests and all ran as Democrats. Eight of the black Democrats ran for open seats while 22 contests had black incumbents. Only one African American challenged a sitting Republican.

The models include variables measuring campaign spending, candidate quality, white voter partisanship, and a dummy accounting for the 1994 Republican surge. These variables have been found by others to impact the performances of congressional candidates. Candidates who have advantages in political experience and campaign funding generally attract larger shares of the vote (Jacobson 1997; Gaddie and Bullock 2000). All campaign finance figures are taken from appropriate editions of the Almanac of American Politics and have been used to calculate the percentage of the election's total expenditures made by the Democratic candidate. For each contested election, issues of the Almanac of American Politics, Politics in America, Congressional Quarterly Weekly Reports and the Southern Political Report were reviewed to determine whether the non-incumbent candidate(s) had held elected office. Candidate quality was operationalized as a relative 
Table 1. Republican Strength in Arkansas, 1960-2000

\begin{tabular}{|c|c|c|c|c|c|c|}
\hline \multirow[b]{2}{*}{ Variable } & \multicolumn{2}{|c|}{$\begin{array}{l}\text { Democratic } \\
\text { Challengers }\end{array}$} & \multicolumn{2}{|c|}{$\begin{array}{l}\text { Democratic Open } \\
\text { Seat Candidates }\end{array}$} & \multicolumn{2}{|c|}{$\begin{array}{l}\text { Democratic } \\
\text { Incumbents }\end{array}$} \\
\hline & Mean & SD & Mean & SD & Mean & SD \\
\hline Relative spending & 18.47 & 17.29 & 61.32 & 27.18 & 79.54 & 14.56 \\
\hline Relative experience & -0.74 & 0.44 & 0.37 & 0.83 & 0.87 & 0.34 \\
\hline $\begin{array}{l}\text { White presidential } \\
\text { partisanship }\end{array}$ & -1.35 & 4.46 & 0.66 & 4.55 & 0.89 & 4.71 \\
\hline 1994 contest & 0.17 & - & 0.26 & - & 0.41 & - \\
\hline Black candidate & 0.03 & - & 0.37 & - & 0.56 & - \\
\hline $\mathrm{N}$ & & 35 & & 19 & & 39 \\
\hline
\end{tabular}

measure of electoral experience taking on the value of 1 if the Democrat had held prior office and the Republican opponent did not; -1 if the roles were reversed; and 0 if neither or both party nominees had previously held elected office.

Advocates of the colorblind hypothesis often suggest that white voters' partisanship explains their low support for black congressional candidates running under the Democrat label. To account for underlying partisan orientation of the district's white voters, we take advantage of the high level of support among African American voters for Clinton in the 1992 and 1996 elections (Tate 1995; Pomper 1997). Following Fleisher (1993) and Berard and Rohde (1998), the residual from regressing the district's Democratic two-party presidential vote in the most recent election on percent black population serves as an indicator of the partisan leanings of the district's white voters. Higher values for the residual measure indicate a greater white willingness to support Democratic candidates. Inclusion of a white presidential partisanship variable should control for the large number of southern whites in many districts who are unlikely to vote for any Democratic congressional candidate, regardless of their race.

According to the color blind hypothesis, a dummy variable indicating that the Democratic nominee is black should be insignificant for Democratic open seat candidates and incumbents. If, however, the incumbency hypothesis is correct, the dummy variable for black incumbents should be insignificant while the coefficient for blacks seeking open seats should be negative and significant.

Coefficients and standard errors for the candidate's race were calculated from a single equation OLS model with terms representing the interaction of each variable with the candidate's electoral status. Because the dependent variables used in the analysis are estimates and the variance of 
these estimates is likely correlated with independent variables used in the analysis, a heteroskedastic disturbance term is expected. T-tests for the significance of the black Democratic candidate variable in the analysis that follows are based on "robust" or heteroskedasticity-consistent standard errors (White 1980; Beck 1995).

Before examining support for the color blind and incumbent hypotheses, we see whether support exists for the greater tolerance hypothesis. If whites have become more tolerant, then black candidates should get larger shares of the white vote than a generation ago. Black congressional candidates in our sample polled approximately a third of the white vote, substantially more than the ten percent white crossover vote observed by Loewen (1987) in earlier South Carolina contests. ${ }^{11}$

\section{Findings}

Models with identical independent variables are estimated for each of three measures of white support for the Democratic nominee. Table 2 presents the model using OLS estimates, Table 3 presents the King ecological inference results, and Table 4 relies on homogeneous precinct estimates of white preferences. Each model includes controls for spending, candidate experience, the share of the white vote going to the Democratic presidential nominee, and a dummy variable for 1994. The results are sufficiently similar across the three measures of the dependent variable so that they can be discussed simultaneously.

The results provide no support for the white color blind hypothesis. Black Democrats competing for open seats, receive between 14.3 and 18.7 less of the white vote than do white Democrats comparable to the black Democrats in terms of relative spending and experience and in districts similarly inclined toward Democratic presidential nominees.

McKinney's incumbency thesis suggests that any disadvantage confronted by African Americans seeking to get to Congress will be attenuated in reelection bids. The second model in each table provides no support for McKinney's proposition as black incumbents attract 13 to 17.2 percentage points less white support than do sitting white Democrats. Despite McKinney's belief that incumbency saved her when the white population in her district increased by 27 percentage points, the results in Tables 2-4 show that black incumbents are almost as disadvantaged as African Americans contesting open seats. The greatest disparity occurs using OLS estimates and it shows black incumbents drawing 16.55 percent less of the white vote while black open seats candidates get 18.66 percent less of the white vote than comparable white Democrats. The model using EI estimates shows that incumbency reduces the disadvantage confronted by black candidates by 
Table 2. Model of White Support for Democratic Congressional Candidates (OLS Estimates)

\begin{tabular}{|c|c|c|c|}
\hline Candidate Status & Variable & Coefficient & $t$-statistic \\
\hline \multirow[t]{6}{*}{ Open seat } & Relative Spending & 0.26 & 3.49 \\
\hline & Relative experience & 0.73 & 0.60 \\
\hline & White presidential partisanship & 0.57 & 1.76 \\
\hline & 1994 contest & -7.69 & -3.19 \\
\hline & Black candidate & -18.66 & -8.90 \\
\hline & Constant & 30.50 & - \\
\hline \multirow[t]{6}{*}{ Democratic incumbent } & Relative spending & 0.23 & 1.89 \\
\hline & Relative experience & 5.28 & 2.23 \\
\hline & White presidential partisanship & 0.17 & 0.58 \\
\hline & 1994 contest & -3.07 & -1.13 \\
\hline & Black candidate & -16.55 & -5.69 \\
\hline & Constant & 27.14 & - \\
\hline \multirow[t]{6}{*}{ Democratic challenger } & Relative spending & 0.20 & 3.21 \\
\hline & Relative experience & 4.55 & 1.79 \\
\hline & White presidential partisanship & 0.74 & 3.47 \\
\hline & 1994 contest & -2.74 & -1.01 \\
\hline & Black candidate & -10.32 & -3.71 \\
\hline \multirow{2}{*}{\multicolumn{2}{|c|}{ Constant }} & 31.41 & - \\
\hline & & \multicolumn{2}{|c|}{0.68} \\
\hline \multicolumn{2}{|l|}{$N$} & & \\
\hline \multicolumn{4}{|c|}{$\begin{array}{l}\text { Notes: Dependent variable is OLS estimate of percent white support for Democratic candidates. Unit } \\
\text { of analysis is the congressional district. Coefficients calculated from single equation with interaction } \\
\text { terms estimated with OLS. Absolute } t \text {-statistics based on robust (heteroskedastic-consistent) standard } \\
\text { errors. }\end{array}$} \\
\hline
\end{tabular}

Table 3. Model of White Support for Democratic Congressional Candidates (EI Estimates)

\begin{tabular}{llrc}
\hline Candidate Status & Variable & Coefficient & $t$-statistic \\
\hline \multirow{2}{*}{ Open seat } & Relative spending & 0.20 & 4.82 \\
& Relative experience & 0.07 & 0.06 \\
& White presidential partisanship & 0.84 & 2.89 \\
& 1994 contest & -6.56 & -3.03 \\
& Black candidate & -14.33 & -6.73 \\
& Constant & 34.45 & - \\
Democratic incumbent & Relative spending & 0.21 & 2.32 \\
& Relative experience & 4.27 & 1.65 \\
& White presidential partisanship & 0.24 & 1.16 \\
& 1994 contest & -4.94 & -2.54 \\
& Black candidate & -13.04 & -7.10 \\
& Constant & 30.57 & -
\end{tabular}


Table 3 (continued)

\begin{tabular}{llrc}
\hline Candidate Status & Variable & Coefficient & $t$-statistic \\
\hline \multirow{2}{*}{ Democratic challenger } & Relative spending & 0.22 & 3.17 \\
& Relative experience & 3.38 & 1.18 \\
& White presidential partisanship & 0.67 & 3.19 \\
& 1994 contest & -3.86 & -1.28 \\
& Black candidate & -5.01 & -1.58 \\
& Constant & 31.82 & - \\
$\mathrm{R}^{2}$ & & \multicolumn{2}{c}{0.75} \\
$N$ & & \multicolumn{2}{c}{86}
\end{tabular}

Notes: Dependent variable is King's (1997) ecological inference estimate of percent white support for Democratic candidates. Unit of analysis is the congressional district. Coefficients calculated from single equation with interaction terms estimated with OLS. Absolute $t$-statistics based on robust (heteroskedastic-consistent) standard errors.

Table 4. Model of White Support for Democratic Congressional Candidates (HP Estimates)

\begin{tabular}{llrr}
\hline Candidate Status & Variable & Coefficient & $t$-statistic \\
\hline \multirow{2}{*}{ Open seat } & Relative spending & 0.30 & 2.63 \\
& Relative experience & 0.43 & 0.22 \\
& White presidential partisanship & 0.38 & 0.77 \\
& 1994 contest & -4.98 & -1.80 \\
& Black candidate & 17.04 & -5.14 \\
& Constant & 28.19 & - \\
Democratic incumbent & Relative spending & 0.20 & 1.65 \\
& Relative experience & 5.12 & 1.68 \\
& White presidential partisanship & 0.16 & 0.55 \\
& 1994 contest & -3.50 & -0.93 \\
& Black candidate & -17.22 & -4.93 \\
& Constant & 29.70 & - \\
Democratic challenger & Relative spending & 0.17 & 2.68 \\
& Relative experience & 4.36 & 1.73 \\
& White presidential partisanship & 0.68 & 3.34 \\
& 1994 contest & -5.55 & -2.03 \\
& Black candidate & -8.38 & -3.03 \\
$\mathrm{R}^{2}$ & Constant & 34.66 & - \\
$N$ & & & 0.54 \\
& & & 93 \\
& & &
\end{tabular}

Notes: Dependent variable is homogenous precinct estimate of percent white support for Democratic candidates. Unit of analysis is the congressional district. Coefficients calculated from single equation with interaction terms estimated with OLS. Absolute t-statistics based on robust (heteroskedasticconsistent) standard errors. 
only about 1.25 percentage points. The model using homogenous precinct estimates shows no reduction associated with incumbency.

The persistence of a disparity in the share of the white vote polled by black incumbents is at variance with Hajnal's conclusion that "A black candidate loses for much the same reasons as a white candidate loses" (2001, 614). While incumbency boosts the share of the vote going to a candidate, House service has done little to mute the difference in the share of white votes won by a black Democrat when compared to a white Democrat. Even after gaining experience in the House, black legislators remain disadvantaged vis-à-vis comparably situated white Democrats. These results may conflict with Hajnal's findings because being a member of Congress pays fewer dividends than being mayor. Fewer whites may credit the new black legislator with continued or even improved conditions and thus be less likely to rethink stereotypes held when the black was initially elected. The reassessment that Hajnal found may have been more likely because of the higher visibility and greater influence on policy exercised by a mayor compared with a member of Congress.

The third model in Tables 2-4 estimates white support for Democrats who challenged a Republican incumbent. These are not helpful in differentiating levels of white support depending on the race of the Democratic nominee since a single African American fell in this category.

Each model explains at least half the variance with the model using estimates of white behavior derived from homogeneous white precincts being the least successful. The model that measures the dependent variable using King's EI approach explains almost three-quarters of the variance while the model using estimates of white support using OLS accounts for more than two-thirds of the variance.

Looking briefly at the other independent variables, the share of the white vote going to Democratic nominees is always positively related to the share of all campaign spending accounted for by the Democrat. Although the relationship tends to be weaker, Democrats who are more experienced than their opponent get larger shares of the white vote when they are incumbents seeking an additional term. Using OLS and homogeneous precinct estimates also shows a tendency for more experienced Democrats to get more white votes when challenging a Republican incumbent. Relative experience never plays a role in the estimates for open seats. Although never a significant factor in contests in which the Democrat is an incumbent, the share of the white vote for Democratic presidential candidates is often positively related to the share of the white vote won by non-incumbent congressional Democrats. As expected, Democrats polled less of the white vote in 1994; the dummy variable for that year always has a negative sign and in five of the estimates, it achieves statistical significance using a one-tailed test. 
Another perspective on the incumbency hypotheses compares the share of the white vote won by black incumbents against the share of the white vote they won in their initial contests. Even though black incumbents do not run as well among white voters as white incumbents, they may have done better than in their first outing. The EI estimates show that 20 black incumbents got 37.5 percent of the white vote compared with 32 percent for four blacks seeking open seats. The other approaches for which we have more observations show seven black non-incumbents averaging 34.1 percent of the white vote using OLS and 35.2 percent of the vote in homogenous white precincts. Mean white support for 25 black incumbents is very similar, averaging slightly less with 33 percent using OLS and 34.2 percent in homogenous white precincts.

Table 5 approaches the effect of incumbency from another angle. It presents estimates of white support over time for six of the African-Americans initially elected in 1992. Sanford Bishop and James Clyburn attracted more white votes in 1994 than 1992 while Cynthia McKinney, Eva Clayton and Robert Scott were less successful. Clyburn, Corrine Brown and Bishop got more white votes in 1996 than in 1992 although Bishop, whose district had been redrawn to make it whiter, did less well than in 1994. McKinney, whose district had also been redrawn, and Clayton fared worse in 1996 than four years earlier. In their third re-election bids, Bishop and Clyburn had more white support than in their initial bids with Clyburn having his greatest appeal so far. McKinney had rebounded from the drop in white support immediately after the 1995 redistricting. Clayton continued to get no more than a third of the white vote and had not attained the support she enjoyed in her initial election. Her 1998 performance may have been hampered by having to compete in a district that had been redrawn. The mixed nature of the results fails to demonstrate a consistent pattern of enhanced performance associated with incumbency.

\section{Conclusion}

The analysis of almost 100 congressional general election contests in the South shows that white voters remain less supportive of black Democratic nominees. Differences in the level of white support persist regardless of whether the black Democrat is an incumbent or contests an open seat. Thus we can reject the colorblind hypothesis. Contrary to the incumbency thesis, African-American incumbents do not do better with white voters, relative to the performance of white incumbents. When compared with similarly-situated white Democrats, African American incumbents' disadvantage among white voters is almost as great as that of black Democrats seeking open seats. Nor do blacks get consistently larger shares of the white vote once they become incumbents. 
Table 5. White Support Over Time for Selected Blacks Initially Elected to Congress in 1992

\begin{tabular}{|c|c|c|c|c|}
\hline Characteristic & 1992 & 1994 & 1996 & 1998 \\
\hline \multicolumn{5}{|c|}{ FL-3 Corrine Brown } \\
\hline OLS & 26.0 & NA & 36.2 & NA \\
\hline EI & 27.2 & 39.0 & & \\
\hline $\mathrm{H}$ & 23.5 & 35.5 & & \\
\hline \multicolumn{5}{|c|}{ GA-2 Sanford Bishop } \\
\hline OLS & 30.0 & 40.0 & 37.4 & 37.8 \\
\hline EI & 33.2 & 42.7 & 37.7 & 39.5 \\
\hline $\mathrm{H}$ & 34.0 & 38.1 & 36.6 & 41.3 \\
\hline \multicolumn{5}{|c|}{ GA-4 Cynthia McKinney } \\
\hline OLS & 31.6 & 23.8 & 30.7 & 34.9 \\
\hline EI & 37.9 & 32.5 & 32.1 & 36.2 \\
\hline $\mathrm{H}$ & 38.4 & 31.6 & 30.7 & 36.8 \\
\hline \multicolumn{5}{|c|}{ NC-1 Eva Clayton } \\
\hline OLS & 33.9 & 24.1 & 27.9 & 27.9 \\
\hline EI & NA & 32.8 & 34.3 & 33.0 \\
\hline $\mathrm{H}$ & 34.6 & 34.8 & 28.6 & 29.6 \\
\hline \multicolumn{5}{|c|}{ SC-6 James Clyburn } \\
\hline OLS & 22.7 & 25.7 & 30.3 & 32.0 \\
\hline EI & 29.5 & 32.1 & 35.7 & 37.1 \\
\hline $\mathrm{H}$ & 20.4 & 25.2 & 29.7 & 30.8 \\
\hline \multicolumn{5}{|c|}{ VA-3 Robert Scott } \\
\hline OLS & 50.7 & 46.5 & NA & NA \\
\hline EI & NA & NA & & \\
\hline $\mathrm{H}$ & 60.1 & 52.7 & & \\
\hline
\end{tabular}

Figures not presented here demonstrate that although black candidates show greater strength than do white Democrats among African-American voters, the differences are substantially less than the disparities estimated in the white electorate. While black nominees usually poll at least 95 percent of the black vote, white Democratic incumbents and open seat candidates regularly get 90 percent or more of the black vote and even whites challenging Republicans never fail to get 80 percent or more of the black vote.

Lest these results appear too bleak, compared with a white electorate that once refused to support black candidates, southern voters have become more tolerant. Black incumbents who had average advantages in spending or 
experience, competed in a district in which white support for Democratic presidential nominees was average and ran in a year other than 1994 are predicted to receive between 33 (Table 4) and 33.6 (Table 2) percent of the white vote. In 1994, the range in the estimated white vote for black incumbents in "average" districts is 29.5 to 30.6 percent. The estimated share of the white vote for a black Democrat competing for an open seat in an "average" district in a year other than 1994 ranges from 28.4 (Table 2) to 30 (Table 4) percent. No blacks ran for open seats in 1994, but had they done so, the expected share of the white vote in "average" districts would have ranged from 20.7 to 25 percent. While black candidates fail to win white votes at the same rate as white Democrats, their success in attracting as much as 40 percent of the white vote indicates that the white backlash model no longer accurately describes southern voting patterns.

Our models suggest that incumbency provides a modest boost in white votes going to an African American. When other independent variables are set at their means, the models predict that a black incumbent will run several percentage points better among whites than will a black seeking an open seat. While the differences are not large, they could enable an incumbent to win reelection narrowly where a black open seat candidate would fail.

Despite greater tolerance that enables black candidates to attract a share of the white vote, the continuing disparities reported here should be considered when drawing districts. An implication of the findings is that an African American needs a district to be somewhat blacker than would a white Democrat to have the same chance at election. However, so long as African Americans poll shares of the white vote similar to that observed here, it will not be necessary to draw districts having extraordinary black majorities for African Americans in order to have reasonable chances to elect their candidates of choice. This will permit the redistribution of more blacks in order to bolster prospects of Democratic candidates-both black and white - in a greater number of districts.

\section{NOTES}

${ }^{1}$ DOJ denies ever having had a 65 -percent rule.

${ }^{2}$ Georgia created two new majority-black districts in 1992 , the 2 nd which was $57 \%$ black and the 11 th which was $64 \%$ black.

${ }^{3}$ During the last decade, the only majority-black district electing a white has been Pennsylvania's 1st district.

${ }^{4}$ The tradeoff between the concentration of minorities and the assurance that a minority would be elected was acknowledged and seemingly granted approval in Georgia v. Ashcroft, 123 S.Ct. 2498 (2003).

${ }^{5}$ Louisiana's Cleo Fields who would have had to run against another incumbent after his district was dismembered ran for governor rather than reelection to the House. 
Cynthia McKinney lost the 2002 primary but by that time redistricting had boosted the district's black population above 50 percent.

${ }^{6}$ The 2000 census showed a population change so that almost half her district's population was then black.

${ }^{7}$ All contested elections from Georgia for the time period are included. All contested elections from North Carolina for 1994 through 1998 and the Eva Clayton's (D-NC) 1992 victory are included in the data set. All contested elections during 1996 and 1998 in South Carolina as well as the (re)election of James Clyburn (D-SC) and John Spratt (D-SC) are included as well. Election results for the thousands of North and South Carolina precincts back to 1992 are not available in computer readable format which explains why our data for these states are less comprehensive than for Georgia.

${ }^{8}$ Unfortunately, the other two southern states that maintain such statistics (Florida and Louisiana) do not make precinct-level registration figures and electoral results widely available in computer-readable formats. Without such easily accessible data, analysis of a large number of congressional districts is not feasible. Estimates of voting preference by race can also be made using the racial composition of the voting age population or the total population as the independent variable. This also necessitates collecting data on thousands of precincts - a daunting task. Moreover Louisiana's unique electoral system raises questions about comparability.

${ }^{9}$ The additional contests are FL-3 for 1992 and 1996, VA-3 for 1992, and 1994, LA-4 for 1994, TX-18, 29 and 30 for 1992 and 1994.

${ }^{10}$ The estimates of white support for Democratic candidates that form the dependent variables in this study are available, with a few exceptions, at Bullock and Dunn (1999).

${ }^{11}$ The average white crossovers were 33.6 percent for the OLS estimates, 34.7 percent in homogeneous precincts and 38.2 percent for EI estimates.

\section{REFERENCES}

Aistrup, Joseph A. 1996. The Southern Strategy Revisited: Republican Top-Down Advancement in the South. Lexington: University of Kentucky Press.

Beck, Nathaniel. 1995. Reporting Heteroskedasticity Consistent Standard Errors. The Political Methodologist 7:4-6.

Berard, Stanley P., and David Rohde. 1998. What You See Is ... Essentially ... What You Get: House Races in the Contemporary South. Paper presented at the Annual Meeting of the Midwest Political Science Association, Chicago, IL, April 23-25.

Brace, Kimball, Bernard Grofman and Lisa Handley. 1987. Does Redistricting Aimed to Help Blacks Necessarily Help Republicans? Journal of Politics 49:169-185.

Brace, Kimball, Bernard Grofman, Lisa R. Handley, and Richard G. Niemi. 1988. Minority Voting Equality: The 65 Percent Rule in Theory and Practice. Law and Policy 10:48-62.

Bullock, Charles S., III. 1987. Redistricting and Changes in the Partisan and Racial Composition of Southern Legislature. State and Local Government Review 19:62-67.

Bullock, Charles S., III. 1988. Regional Realignment from an Officeholding Perspective. Journal of Politics 50:553-574.

Bullock, Charles S., III. 1996. Racial Composition of District Population and the Election of African-American Legislators. Southeastern Political Review 24:611-628.

Bullock, Charles S., III, and Richard E. Dunn. 1999. The Demise of Racial Districting and the Future of Black Representation. Emory Law Journal 48:1209-1253. 
Bullock, Charles S., III, and Mark J. Rozell. 1998. Southern Politics at the Century's End. In The New Politics of the Old South, ed. Bullock and Rozell. Lanham, MD: Rowman and Littlefield.

Burton, Orville Vernon. 1998. Legislative and Congressional Districting in South Carolina. In Race and Redistricting in the 1990s, ed. Bernard Grofman. New York: Agathon.

Cameron, Charles, David Epstein, and Sharyn O’Halloran. 1996. Do Majority-Minority Districts Maximize Black Substantive Representation in Congress? American Political Science Review 90:794-812.

Engstrom, Richard L. 1995. Voting Rights Districts: Debunking the Myths. Campaigns and Elections 16:24-46.

Engstrom Richard L. and Jason E. Kirksey. 1998. Race and Representational Districting in Louisiana. In Race and Redistricting in the 1990s, ed. Bernard Grofman. New York: Agathon.

Epstein, David, and Sharyn O'Halloran. 1999. A Social Science Approach to Race, Redistricting, and Representation. American Political Science Review 93:187-191.

Fleisher, Richard. 1993. Explaining the Change in Roll-Call Voting Behavior of Southern Democrats. Journal of Politics 55:327-341.

Gaddie, Ronald K., and Charles S. Bullock, III. 2000. Election to Open Seats in the U.S. House. Lanham, MD: Rowman and Littlefield.

Gay, Claudine. 2001. The Effect of Black Congressional Representation on Political Participation. American Political Science Review 95:589-602.

Hagens, Winnett W. 1998. The Politics of Race: The Virginia Redistricting Experience, 1991-1997. In Race and Redistricting in the 1990s, ed. Bernard Grofman. New York: Agathon.

Hajnal, Zoltan L. 2001. White Residents, Black Incumbents, and a Declining Racial Divide. American Political Science Review 95:603-617.

Holmes, Robert A. 1998. Reapportionment Strategies in the 1990s: The Case of Georgia. In Race and Redistricting in the 1990s, ed. Bernard Grofman. New York: Agathon.

Jacobson, Gary C. 1997. The Politics of Congressional Elections, 4th ed. New York: Longman.

King, Gary. 1997. A Solution to the Ecological Inference Problem. Princeton, NJ: Princeton University Press.

Liu, Baodong, and James M. Vanderleeuw. 1999. White-Voter Response to Black Political Power: The Case of New Orleans, 1980-1994. Southeastern Political Review 27:175-188.

Loewen, James H. 1982. Testimony published in Extension of the Voting Rights Act. Hearings before the subcommittee on Civil and Constitutional Rights, House Judiciary Committee. Washington, DC: U.S. Government Printing Office.

Loewen, James H. 1987. Racial Bloc Voting in South Carolina. Unpublished.

Lublin, David. 1997. The Paradox of Representation. Princeton: Princeton University Press.

Lublin, David. 1999. Racial Redistricting and African American Representation: A Critique of "Do Majority Minority Districts Maximize Substantive Black Representation in Congress?" American Political Science Review 93:183-186.

McKinney, Cynthia A. 1996. A Product of the Voting Rights Act. Washington Post (November 26):A15.

Pomper, Gerald M. 1997. The Presidential Election. In The Election of 1996: Reports and Interpretations, ed. Gerald M. Pomper et al. Chatham, NJ: Chatham House. 
Tate, Katherine. 1995. Structural Dependence or Group Loyalty? The Black Vote in 1992. In Democracy's Feast: Elections in America, ed. Herbert F. Weisberg. Chatham, NJ: Chatham House.

Thernstrom, Stephan, and Abigail Thernstrom. 1997. America in Black and White. New York: Simon and Schuster.

Vanderleeuw, James M. 1989. The Impact of Race and Incumbency on Voting Behavior and Local Elections. Presented at the annual meeting of the American Political Science Association.

Voss, D. Stephen, and David Lublin. 2001. Black Incumbents, White Districts. American Politics Research 29:141-182.

Watson, S.M. 1984. The Second Time Around: A Profile of Black Mayoral Election Campaigns. Phylon 45:165-175.

White, Halbert. 1980. A Heteroskedasticity-Consistent Covariance Matrix and a Direct Test for Heteroskedasticity. Econometrica 48:817-838. 
